\title{
Research on the Influence Factor and Practical Process of Venture Philanthropy
}

\author{
Pan Lin 1,2 \\ ${ }^{1}$ The School of Public Affairs, University of Science and Technology of China, Hefei, China \\ ${ }^{2}$ Anhui Economic Management Institute, Hefei, China \\ Email:1pcheney@mail.ustc.edu.cn
}

How to cite this paper: Lin, P. (2018) Research on the Influence Factor and Practical Process of Venture Philanthropy. Open Journal of Social Sciences, 6, 175-187. https://doi.org/10.4236/jss.2018.61013

Received: December 21, 2017

Accepted: January 23, 2018

Published: January 26, 2018

Copyright $\odot 2018$ by author and Scientific Research Publishing Inc. This work is licensed under the Creative Commons Attribution-NonCommercial International License (CC BY-NC 4.0).

http://creativecommons.org/licenses/by-nc/4.0/

\begin{abstract}
Venture philanthropy provides new supports to social services in the form of innovative projects, and has a step-by-step progress. The subject of a prefect venture philanthropy includes donors, recipients, beneficiaries and independent qualified Third-Party Assessment Entities. The venture philanthropy has an interactive process, which consists of the following four steps: project collection and training, field visits and project optimization, project review and publicity, and signature of the protocol. Venture philanthropy can promote the concept that governments can buy public service from other organizations, and advance win-win cooperation between the government and the social organizations. The government supports the benign development of public organizations and guides the practice of public venture capital in order to serve the masses, forming a multi body participation in social governance innovation pattern. This paper have studied the venture philanthropy practice, analyzed the influencing factors of the venture philanthropy, and summarized the relationship between the venture philanthropy process and the subjects on the basic of the field investigation of China's venture philanthropy.
\end{abstract}

\section{Keywords}

Venture Philanthropy, Non-Profit Organizations, Influence Factors, Practice Process

\section{Introduction}

Originated from Europe and America, venture philanthropy is a new kind of public partnership and philanthropic investment model, which is widely used in the world. In the 1990s, it rose rapidly with the rise of the Internet industry. According to statistics, in the last 10 years, at least 42 institutions engaged in public 
welfare ventures have been established in the United States. By 2006, there were 36 venture capital organizations in Europe. Since 2009, there has been a steady increase in interest at countries besides the United States and Europe, especially for Asian countries. India, Singapore, Japan, China, South Korea, Australia and other countries and regions have begun to explore the theory and practice of venture capital investment.

At present, venture philanthropy has become one of the most frontier attempts with wide social acceptance [1]. Local governments flock to start venture philanthropy projects. With the promotion of government agencies at all levels and social forces, venture philanthropy has entered the development stage in China. However, venture philanthropy also has some unsolved problems. If we do not appreciate and solve them in time, venture philanthropy may go along the wrong direction. Therefore, what has attracted many researchers' attention is how to support and encourage public welfare organizations and guide the direction of venture philanthropy projects. Public welfare organizations with benign development can serve the necessary people in a better way. The venture philanthropy is a new exploration model of governments purchasing public services. It can contribute to the cultivation and development of public welfare organizations and support public welfare organizations to participate in public affairs and good causes. Therefore, the paper discusses the influencing factors and practice process of venture philanthropy. It may have good demonstration effects on the promotion of government purchasing innovation model.

\section{The Meaning and Discrimination of Venture Philanthropy}

Venture philanthropy, originated in America in the late 1990s, is firstly proposed by an American philanthropist John D. Rockefeller in 1969. It is a special form of financial aid funding with certain risks to solve the special social ills. The peninsula community foundation of America firstly used Venture Philanthropy to express the combination of business ventures and financing behavior at 1984 . Letts et al. (1997) [2] proposes to use the sponsorship fund model to support non-profit organizations, and the charitable foundation can borrow the method of venture capital.

In 2001, the first China-Europe venture capital conference held in Budapest, Taiwan scholar Bayashi Yoshiro firstly translated the concept as "Venture Philanthropy". In 2007, he further defined this concept of Venture Philanthropy as a kind of public investment, namely a long-term investment with double bottom-line which means a commercial venture fund mode possessing the non-profit mission and essence. The basic strategy is that Venture Philanthropy subsidize non-profit organizations or social enterprises, and assist their constructions of internal management level or technical tools.

In the middle and early $90 \mathrm{~s}$, most of venture philanthropists in west countries were in the exploratory practice stage, and few theoretical researches were reported. The main researches focused on the concept, characteristics and invest- 
ment skills of venture philanthropy. Until the late twentieth Century and early 90s, the theoretical research of venture philanthropy was gradually mature and systematic. Mario Moran (2010) [3], one of the representatives, defined American public risk investment and counted the successful venture philanthropy cases in the United States. He tried to distinguish between the traditional charity and the new public risk investment through introducing the concept "expectations continuum". In addition, Rober John (2010) [4] summarizes six main characteristics and three basic characteristics of venture philanthropy. They are highly participatory, tailored financial arrangements, long-term financial support, financial support, organizational capacity building, performance evaluation and financial capital, knowledge capital and social capital respectively.

From the above, venture philanthropy has been widely applied in the world. Venture philanthropy is a new kind of public welfare subsidy mode which brings the idea and technology of venture capital investment into the public welfare. It promotes the governments to outsource the public service function to the social organization, cultivate and develop the public welfare social organization, promote its standard management, enhance the professional service ability, and thus make it effectively meets and solves the social public service demand. It makes social organizations achieve the transformation from the "blood transfusion" function to "hematopoietic" function.

Venture capital requires long-term and participatory cooperation between sponsors and nonprofits, emphasizing that donors and recipients are no longer simple donations, and more importantly, long-term, in-depth partnerships with investors. This partnership is a win-win situation for both parties: the partners can grow faster, and the sponsor is more efficient in achieving the initial social goals [5]. After evaluating the ability of the subsidized organization, the sponsor provided long-term support for more than three years, including finance, management, technology and many other aspects, and participated in the operation of the organization, and drew up the exit strategy. The goal of public venture investment is to enhance the capacity building of non-profit organizations and improve the efficiency of public welfare and social services through the application of risk management, multi-faceted assistance and performance evaluation. Venture capital is similar to the commercial investment behavior in the mode of operation [6]. The difference between it and the nature of the commercial investment lies in the public welfare of its investment target: it does not require a return or the return on investment will continue to be used for public welfare undertakings.

\section{The Influence Factor of Venture Philanthropy}

\subsection{The Guidance of Venture Philanthropy at National Level}

The premise of non-profit organization's active participation in public affairs is system guarantee, and the guarantee of the system depends on more sound legal policy and law system. The formulation and implementation of policies and laws 
and regulations is one of the important factors to guide the healthy development of venture philanthropy.

1) Policy Guidance

In recent years, the government strengthens policies to support of the development of social organizations and government services to buy. They constantly improve the relevant policy system and optimize the public venture policy environment. The 18th National Congress of the Communist Party of China proposed to strengthen the social construction in improving people's livelihood and innovation management, and put forward the strategic task of constructing the modern social organization system of "separation of government and society, clear responsibility and autonomy according to law". Since then, the relevant social policies continue to establish and improve. In 2012, our state promulgated the Guiding Opinions on the Government's Purchase of Social Work Services, and encouraged the government to purchase services from private social organizations. 2013, our state issued "the Guidance on the government purchasing services from the social forces by General Office of the State Council”, and proposed to mobilize social forces to build multi-level, multi-way public service supply system. In a good national policy support environment, the local government has also introduced a local policy support system with local characteristics.

2) “Top floor design" for venture philanthropy

On the basis of investigation and research, we will extensively absorb the opinions and suggestions of civil affairs departments, scientific research institutions, social enterprises, public welfare organizations and citizens at all levels. We may promulgate national public welfare investment guidance to integrate the strength of government, enterprises and social organizations and citizens to solve social problems as soon as possible. All localities and departments can formulate the project application and finance provided to the social organizations on the basis of the national guidance. They can formulate the actual and scientific and feasible public welfare venture plan, implementation plans, regulations to better promote the continuous development of public venture which will meet the various public service needs of the community residents. In June 2016, Tianjin issued the first local standard of the public venture "Tianjin social organization charity procedures" (DB12/T634-2016). The procedure made a clear provision on the terminology, definition, process, organization main body, publication of the proposal, project application and approval, project implementation and supervision, project items and post-project evaluation of public venture in social organizations.

\subsection{The Brand Effect of Venture Philanthropy Investment}

Through three aspects, in the practice of venture philanthropy, a brand venture philanthropy project is formed to enhance the brand effect and social credibility of non-profit organizations, so as to improve the service level of social public 
welfare.

1) Improvement of research form of venture philanthropy

At present, the researches and discussions on public venture by academia, public sector are in the ascendant. But for the community level, public venture is still new things, and its familiarity and attention are very limited. Public venture sets public needs of the community residents as the starting point and destination, generally implemented by the public service organization within the community. It cannot carry out without the public attention and support. Therefore, in the process of promoting the development of public welfare venture, we must fully meet the public demand, account for the project awareness and participation of the community residents, solicit venture specific intentions to the community residents, and actively create a community residents to participate in a good atmosphere.

2) Increase project cooperation ability

When social organizations provide public services, the social organizations have ability to undertake the public welfare projects, unfortunately the residents cannot agree and trust the social organizations. It will result in ineffective service. On the other hand, some immature social organizations do not have the ability to undertake some special social public services. So it is necessary to cultivate high-quality social organization and build the brand effect. For example, Hangzhou's JinGuoXiLi family business group have high social awareness and trust after the brand effect in the residents is built, so the recognition of home care service is higher [7]. Social organizations need to cooperate with each other, share resources. For some projects that cannot be undertaken by individual social organizations, it can be undertaken by several social organizations through mutual cooperation to provide residents with high quality public services.

3) Perfect exit mechanism

The investigation found that China's local public venture is a short-term venture capital. Many projects may expiry after being carried out for one year, however such a withdrawal mechanism is not conducive to the development of social organization. Public venture projects are different, of which some have a relatively long investment period and in short-term social benefits is relatively weak. Compared with foreign countries, the withdrawal period of social organizations is relatively long, usually 3 - 6 years. The withdrawal mechanism takes the ability of independent operation as the standard. When the social organization can operate by itself, the government will terminate support and social organizations will work independently or seek the next investor.

China's public welfare venture can consider to cultivate a number of special social organizations based on the annual evaluation of social organizations for a long-term time. Combined with foreign experience and practice in Hangzhou, we can foster potential social organizations, strengthen social forces and achieve social good governance. 


\subsection{Change the Role of Government in Venture Philanthropy}

The key of promoting the innovation of venture capital system is to adjust the role of government. The government should gradually change from leaders, organizers and managers to guiders, regulators and managers of public welfare venture and build a new model in which government, public welfare organizations and social enterprises cooperate and innovate.

The government should actively change the role of the leader of public venture gradually into a capitalist, no longer specifically involved in the implementation of the project. The government should guide and service, and put more work in the hands of social forces through the venture capital project.

The relationship between the government, social enterprises, public welfare organizations and residents can balance the rights and obligations of stakeholders, and realize multiple input and participation.

In terms of participating subjects, the government, social enterprises, public welfare organizations, residents and third-party assessment agencies have formed a collaborative network of governance.

\subsection{Improve the Funding Mechanism for Venture Philanthropy}

The key to the continuous deepening of the public venture is capital. With the support of funds, venture philanthropy can play its role in nurturing innovative organizations, playing the innovative ability of NPO, and promoting social problem solving. Therefore, how to raise more funds, how to ensure the rational use and supervision of funds are important factors to be considered for venture philanthropy.

Diversified financing channels are conducive to the expansion of the fund scale of public funds and the impact of public welfare initiatives. At present, domestic venture philanthropy channel mainly comes from government support, generally composed of welfare lottery ticket public welfare fund and charitable public welfare fund. The local governments carry out the project in the form of public welfare venture competition. The domestic financing from foundation, social enterprises and companies is still in development stage, and the financing range is limited. Government can strengthen the social responsibility by improving the tax policy and establishing incentive mechanism. Taken the enactment of charity law as an opportunity, it can actively guide the social raising public awareness of philanthropy, and constantly perfect public venture capital source channel [8].

The 966.63 million in Hangzhou venture philanthropy project is composed of 2 million from the welfare lottery and the Hangzhou government support. 5 million venture capital funds also came from the Civil Affairs Bureau of Baohe District in Hefei. It may infer that the source of funds of venture philanthropy is still quite unitary and supports from business and social forces are relatively weak. So how to attract public welfare funds is the ability that social organizations should improve. 
When social organizations are assessed, the ability for attracting non-governmental public funds and the amount of social directional donations should be considered as key evaluation indicators. It could encourage public social organizations and project development to attract social directional donations [9]. The incorporation of public welfare funds can provide comprehensive support to social organizations, such as capital, technology, manpower, management and other resources, so that social organizations can sustainably carry out public welfare activities to achieve some social benefits.

If public venture capital funds have no appropriate monitoring mechanism, there may be the phenomenon of misappropriation of funds. In order to ensure the mode of operation of community funds is science, reasonable and transparent, the corresponding public venture capital fund supervision mechanism should be set up. In addition, on the premise of not affecting the normal operation of community equity venture capital, a reasonable limit of funds should be developed to avoid waste of funds.

\subsection{Improve the Performance Evaluation Mechanism for Public Welfare Initiatives}

Scientific, effective and perfect evaluation mechanism is very important to the development of venture philanthropy. Whether realizing the rational allocation of public resources, optimizing government supervision and management, or improving the service quality of public venture investment, management performance and credibility, we need a more scientific, effective and perfect evaluation mechanism.

The design of evaluation index of venture philanthropy should pay more attention to the public satisfaction evaluation besides the efficiency and the effect of public welfare venture. The main body of venture philanthropy should be evaluated by the donor (the buyer), clients and professional institutions. The assessment tools should attach importance to economic efficiency, financial sustainability and social value. In the assessment process, we should pay attention to open, transparent, fair, impartial principles to prevent venture philanthropy from favoritism activity. The evaluation of venture philanthropy can be combined with the evaluation of the social organization and the bidding of the government public service project so as to achieve the goal of satisfying the demand of public services and cultivating and developing the social organization through the venture project.

During the operation process of venture philanthropy project, social organizations may pay more attention to the pre-declaration and appraisal of public philanthropy projects. Nevertheless, less attention was paid to the project execution process and the result evaluation. If we do not pay attention to the post-evaluation of public philanthropy projects, it is easy to ignore the problems in the operation and management, and the project funds from the government cannot achieve the greatest social benefits. 
The goal of public venture philanthropy is to foster a group of high-quality social organizations through the government's funds and promote social organizations to participate in public governance. Therefore, the post-evaluation of venture philanthropy projects by the third party evaluation institutions should focus not only on the original service amount and service quality, learning from foreign experience, but also on the ability enhance of social organizations, social impact and other aspects.

\subsection{Promote the Participation of Social Pluralistic Bodies}

In the process of cultivation and development of social organizations, we must mobilize all social forces, social cooperation to motivate social vitality to venture philanthropy.

The venture philanthropy projects operated by NPI or the Amity Foundation, as well as the public project competition activities organized in Shanghai or Shenzhen, have raised a significant portion of the funds through the enterprise. The venture philanthropy projects supported by the enterprise, both can help enterprises to achieve social responsibility and establish a good public image, so as to enhance the reputation of enterprises and product trust and maximize social benefits. It can also invigorate the development of public organizations and promote the public undertakings. With the social responsibility and the public spirit of the companies being promoted, more and more enterprises are willing to participate in public charity to enhance their corporate social image and public welfare marketing impact.

Social organization coordination refers to the benign relationship construction and cooperation between the social organization and government, enterprises, communities and social organizations. The goal of public venture philanthropy is to nurture social organizations, establish trade standards, promote public ideas, cultivate public talents, develop public service, and respond to social needs. Therefore, in the process of development of venture philanthropy we must build a good social organization synergy system in order to effectively integrate a variety of resources, information and services and achieve public objectives.

NPP is a typical social organization synergy collection, which is formed by a number of companies represented by McKinsey and a number of foundations represented by the China Youth Development Foundation. It operates based on a collaborative team jobs. Based on the practical experience of Shanghai and Nanjing, good social organization synergies is necessary to construct venture philanthropy.

Venture philanthropy projects involve multiple industries. For example, venture philanthropy projects in Hefei Baohe District includes "five categories" project: social governance, community construction, professional services, volunteer service category, welfare charity category. The service groups and the project results of the various projects vary widely, and the final development of 
the scientific assessment criteria also need tradeoff. The main source of the project purchase funds is the government and the public, the social organization has the obligation to explain the use of funds, the implementation of the project, to accept the supervision of the public. Only open and transparent operation, scientific and impartial assessment, public venture projects can play the greatest social benefits, serve more residents.

\section{Discussion of the Processes of Venture Philanthropy}

After selecting the research object, the research group to track the observation, analysis of the object of the project implementation process, to make constructive suggestions to improve the preparation. Through the research, look at the development of domestic public venture and the experience around the public venture project implementation process is as follows.

In the whole public venture project, the introduction of a third party evaluation agency-Hefei City fraternity social work development center interested in declaring public welfare project organization to carry out project implementation, resource integration, financial management, process management, team management, project support network construction. As well as the project model combing and promotion of training and counseling, to guide the project design and reporting: A Case Study of the First Public Venture Capital in Baohe District.

Organized by the local Civil Affairs Bureau, from the policy level to explain the public venture and public welfare venture capital project awareness, combined with examples of public venture investment projects how to design, declare a detailed explanation. Taking into account the public welfare venture is still a new thing, the project side of the project before the assessment, in particular, set up the project part of the first instance to guide the declaration unit of the preliminary improvement of the project. The contractor conducted a targeted training session on the issues identified in the preliminary examination. And the project book implementation of the first instance, and for each project book to amend the views. After the expert changes to the proposal, a valid project notification form. The training contents include project packaging, project design, project report writing, financial budget table filling, project evaluation requirements and reporting precautions.

This stage by the public venture project sponsor, from the effective declaration of a number of items randomly selected for field visits. Through the field interviews and project optimization of the applicants and cooperatives, understand the background of the applicant organization or team, design the original intention of the project, plan and plan the project, and the composition of the project team. Authenticity and project operability, and the formation of a visit to the investigation report.

In addition, in view of the financial part of the review, the organizers in accordance with national standards, the recommendations of the Jury and the re- 
quirements and the development of public welfare development of public venture financial management approach documents, unified project optimization requirements and financial budget standards.

By the assessment experts to finalize the list, into the public welfare venture project review the last two links: the project committee (government executive meeting), at the meeting to determine the number of social organizations and public welfare projects into the publicity link, after the announcement. The final generation of public welfare venture to be selected list of projects to determine the amount of funding and the project cycle, usually six months to one year.

By the government and public welfare organizations signed a public welfare venture selected project funding agreement. The selected projects were given 50,000 to 150,000 yuan of funds, investment funds are mainly used for the old service, disabled services, youth services, rescue services and help promote the spirit of volunteer, is conducive to professional social work Improve the service capacity, is conducive to promoting the healthy development of social organizations and public welfare, maintaining family harmony, community harmony, social stability of the service projects, but also for the signing of the social organization to provide targeted capacity-building services to enhance the funding Implementation effectiveness.

Through the research and analysis of the practical process of public venture capital project, we find that in the course of the project practice of public venture, the main body of the perfect public venture includes the sponsor, the recipient, the beneficiary and the independent third party Evaluation agency Quartet. Funded by the sponsor and capacity-building, in the form of public welfare venture to help recipients and public welfare projects, and subvented organizations in the form of project operation of the beneficiaries of the project implementation process, the independent third-party assessment agencies to subsidize of the social organization and the venture capital project to carry out independent assessment and supervision, and the results back to the donor process [10]. The whole public venture project interactive process, aimed to promote the government to buy public service concept to enhance the establishment of government and social organization cooperation and win-win new mechanism, innovation and social governance.

\section{Problems and Difficulties in the Practice of Venture Philanthropy}

Venture Philanthropy is an innovative model for the cultivation and development of non-profit organizations. This new model is seldom used in domestic practice, and the experience of reference is not much. Therefore, with the promotion process of the Venture Philanthropy, the relevant problems in the practice are gradually exposed.

The main body of Venture Philanthropy has not been diversified. The emergence of Venture Philanthropy in China is associated with some well-known en- 
terprises, such as the Legend Group Venture Philanthropy project. But in the ensuing tide, the development of Venture Philanthropy is closely related to government behavior and non-profit organizations, and the role of enterprises and other subjects is less. From the source, Venture Philanthropy is a solution to the development and pressure of the three parties, the government, the enterprise and the non-profit organization. But in the actual operation, the government has become the main body of initiating and promoting Venture Philanthropy. The dominant power of government administration is too strong, and the marketization of Venture Philanthropy has not been formed.

The sustainable development mechanism of Venture Philanthropy has yet to be perfected. Compared with foreign venture Philanthropy, China's venture Philanthropy projects are generally short, long term and persistent, especially lack of continuous funding guarantee mechanism. In Shanghai, Nanjing, Guangzhou and other places of venture Philanthropy, the project cycle is mostly half a year to one year. However, for a certain type of public service, its requirements may be long-term, not simply a single project cycle can be solved [11]. In particular, community governance and community service projects are persistent, and a shorter cycle is not conducive to the progress of the project.

The supply and demand of public service for Venture Philanthropy is not matched. As an innovative carrier of public service supply, the Venture Philanthropy is guided by the demand for public service. However, in the development of many urban Venture Philanthropy projects, the demand for public service of community residents is not compatible with the Venture Philanthropy projects. In the survey of Hefei, we find that some NPO research is not thorough enough. We only plan the service plan based on the original data and traditional thinking mode of the community, resulting in the distortion of service demand. It will affect the actual operation effect of the Venture Philanthropy and the performance of the project.

The evaluation mechanism of Venture Philanthropy is not perfect. At present, the evaluation of Venture Philanthropy is mainly carried out in the way of implementation report, field inspection, third party evaluation and so on. But in the evaluation process, due to the misorientation of evaluation, it is often limited to the output efficiency and result of public service, but neglects the satisfaction evaluation of the audience. In addition, as an important member of the subject of accountability, the absence or loss of the role of the beneficiary is not conducive to the scientific evaluation of the performance of the Venture Philanthropy.

\section{Conclusions and Recommendations}

At present, venture philanthropy driven by the country, local government agencies and social forces at all levels have been blossoming. The interaction between the main bodies has formed a standardized process. And venture philanthropy in China have entered an in-depth development stage. As an innovative mode of government purchase service, public venture has a great reference for promoting 
the government purchase service, promoting the development of social organization and innovating the social governance mode both in theory and practice. But the venture capital in the course of practice also faces some problems and difficulties to be solved. Since it is a try, there will be some unsatisfactory places where governments and social organizations need to grow their space, and both sides need more benign communication. Therefore, the public venture in the course of practice, the need to play a multi-stakeholder participation, integration of the parties platform strength, improve their professional quality. In the platform of venture capital, investment institutions, foundations, government, universities, corporate social responsibility departments need to play their respective strengths, cross-border cooperation to produce the greatest social influence.

This study contributes to the localization development of social governance theory, on the other hand, this study also helps non-profit organizations undertake the government public services and realize their professional, efficient and sustainable development with referential experiences in the background of social governance innovation. The criterion and consummation of venture philanthropy model have practical guiding significance for health development of non-profit organizations. The greatest difficulty in the study of "venture philanthropy" is that its social values and social benefits are difficult to measure. The key of evaluating the venture philanthropy model (including the implementation of the selected projects) is the social values and social benefits of projects. At present, the measurement of social benefits is a major and difficult task to the venture philanthropy. In the future research, the research content of the article will be further deepened and expanded in order to make a little effort for the research of the venture philanthropy under the new situation.

\section{Acknowledgements}

The work described in this paper was supported by a grant from the key humanistic programs of education commission of Anhui province of China (Project No. SK2016A0252).

\section{References}

[1] Lipman, P. (2015) Capitalizing on Crisis: Venture Philanthropy's Colonial Project to Remake Urban Education. Critical Studies in Education, 56, 241-258. https://doi.org/10.1080/17508487.2015.959031

[2] Letts, C.W., Ryan, W. and Grossman, A. (1997) Virtuous Capital: What Foundations Can Learn from Venture Capitalists. Harvard Business Review, 75, 36-50.

[3] Moniro, M. (2010) Overview of Public Operation of Venture Investment in the United States. Wu, M., Trans. Comparative Economic and Social Systems, 4, 135-142.

[4] Rob, J. (2010) The Public Welfare Charity: Highly Involved in the Development of Risk Investment in Europe. Gu, J.M., Trans. Comparative Economic and Social Systems, 4, 143-152.

[5] McCrea, N. (2016) Community Development, Venture Philanthropy and Neoliberal 
Governmentality: A Case from Ireland. In: Rosie, R.M., Ed., Politics, Power and Community Development, 103-120.

[6] Bartek, R.J. (2014) Foundation-Industry Relationships-A New Business Model Joint-Venture Philanthropy in Therapy Development. Current Topics in Medicinal Chemistry, 14, 313-318. https://doi.org/10.2174/1568026613666131127154903

[7] Jing, Y. and Gong, T. (2012) Managed Social Innovation: The Case of Government-Sponsored Venture Philanthropy in Shanghai. Australian Journal of Public Administration, 71, 233-245. https://doi.org/10.1111/j.1467-8500.2012.00767.x

[8] Salzman, R. (2016) Venture Philanthropy and Gene Therapy: Lessons from Adrenoleukodystrophy. Human Gene Therapy, 27, 14-18.

https://doi.org/10.1089/hum.2015.29016.rsa

[9] Zeichner, K. and Pena-Sandoval, C. (2015) Venture Philanthropy and Teacher Education Policy in the US: The Role of the New Schools Venture Fund. Teachers College Record, 117, 1-44. http://www.tcrecord.org

[10] Apple, M.W. (2011) Venture Philanthropy from Government to Governance. 100.

[11] Shiller, J. (2012) Venture Philanthropy's Market Strategies Fail Urban Kids. Phi Delta Kappan, 93, 12-16. https://doi.org/10.1177/003172171209300804 